\title{
ルミノール化学発光法によるペルオキシダーゼ活性を 指標とする玄米の高精度な経時的鮮度変化の評価
}

\author{
野田 博行 ${ }^{\circledR 1}$, 後藤 恒義 ${ }^{2}$, 大矢 博昭 ${ }^{1}$, 鎌 田 仁 $^{1}$
}

\section{Highly Accurate Sensing for a Temporal Change in the Freshness of Brown Rice Using a Chemiluminescence Measurement Combined with a Luminol-Peroxidase System}

Hiroyuki NodA ${ }^{1}$, Tsuneyoshi Goto ${ }^{2}$, Hiroaki OHYA ${ }^{1}$ and Hitoshi KamadA ${ }^{1}$

${ }^{1}$ Institute for Life Support Technology, Yamagata Proportional Organization for Industrial Technology, 2-2-1, Matsuei, Yamagata-shi, Yamagata 990-2473

${ }^{2}$ Yamamoto Co., Ltd., 404, Oinomori, Tendo-shi, Yamagata 994- 8611

(Received 12 July 2004, Accepted 25 August 2004)

\begin{abstract}
Highly accurate sensing for a temporal change in the freshness of brown rice was investigated using a chemiluminescence measurement. The experimental setup was composed of a dark box, a highly sensitive cooled CCD camera (HAMAMATSU, C4880), and a personal computer for data processing. The chemiluminescence intensity was estimated by using a photon counter (HAMAMATSU, C8801). Some pieces of brown rice were placed in the chemiluminescence measurement system. Two kinds of rice, such as new and old ones (stored at one year), were used for chemiluminescence measurements. The addition of 2-methoxyphenol, which is a substrate of peroxidase (POD), led to a decrease in the chemiluminescence intensity of brown rice. Therefore, the luminescence observed may have originated from the POD in brown rice. The chemiluminescence intensity of new rice was fifty-times larger than that of old rice. An increase in the storing period of brown rice at room temperature led to an extreme decrease in the chemiluminescence intensity. Further, the mixture of old and new rice could be distinguished by chemiluminescence imaging. Thus, the chemiluminescence measurement will be a useful technique to evaluate temporal changes in the freshness of brown rice.
\end{abstract}

Keywords : chemiluminescence; imaging; brown rice; freshness; POD.

\section{1 緒言}

平成 15 年産米は, 冷害により 10 年ぶりに不作となっ た。こうなると，銘柄米が不足し，価格の高騰を招くのは もとより，米不足を逆手にとった産地や産年，品種の偽装 が頻発することになる。実際，このような事件が頻発し社 会問題となっている.しかし, 表面化しているのはごく一 部であると推察される。なぜなら，簡単に偽装が見破られ

\footnotetext{
${ }^{1}$ 財団法人山形県産業技術振興機構生物ラジカル研究所：9902473 山形県山形市松栄 2-2-1

2 株式会社山本製作所：994-8611 山形県天童市老野森 404
}

る分析手法がほとんどないからである。良心的な業者にと ってはゆゆしき問題である。またこの問題は，農産物にお ける禁止農薬使用問題とともに生産者や流通業者に対して 消費者が抱く疑念の元となっている.

これまでに著者らは，新米古米の判別などを目的に，電 子スピン共鳴（ESR）法や蛍光イメージング法を用いる米 の鮮度評価技術の開発を行ってきた ${ }^{1) \sim 5)}$. ESR 法は非破壊 で計測でき, 感度も高いが装置が高価であること及び鮮度 低下が進むと判別できないという問題点がある，また，蛍 光画像法は非破壊かつ簡便安価なはん用装置として有用で あるが, 感度の点で ESR 法よりやや劣るという問題点が 


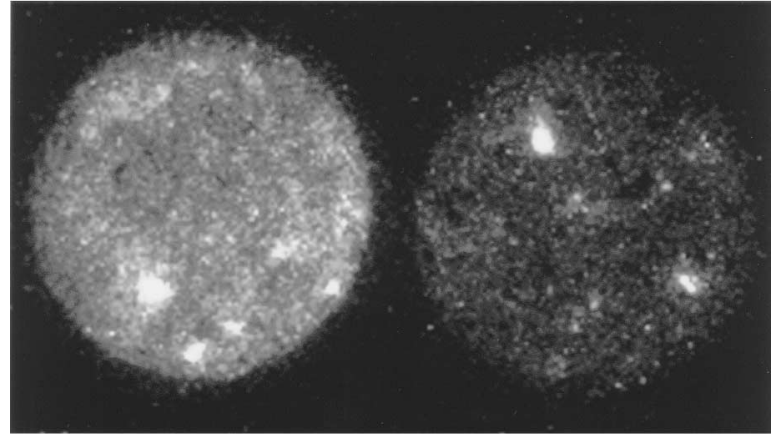

A

B

Fig. 1 Chemiluminescence images of brown rice in the presence (B) or absence (A) of $10 \mathrm{mmol} \mathrm{dm}^{-3} 2-$ methoxyphenol

Sort of rice: Koshihikari; Concentration of luminol: $5 \mathrm{mmol} \mathrm{dm}{ }^{-3}$; Concentration of $\mathrm{H}_{2} \mathrm{O}_{2}: 0.5 \mathrm{~mol} \mathrm{dm}^{-3}$

ある。

そこで種々の検討を重ねた結果, 米の持つペルオキシダ ーゼ（POD）活性を指標としたルミノール化学発光法に より高精度に経時的な玄米の鮮度変化が評価できることを 見いだした ${ }^{6) 7)}$. 以下に, 本研究で得られた結果の詳細を 報告する.

\section{2 実験}

玄米は 2001～2002 年産のコシヒカリ（冷蔵，室温貯蔵， 籾有無）を用いた。ルミノールの $\mathrm{Na}$ 塩, 2-メトキシフェ ノール (グアヤコール)，30\% 過酸化水素溶液及びリン酸 緩衝溶液は和光純薬製を用いた。化学発光イメージング装 置は, 高感度冷却 CCD カメラ（浜松ホトニクス製 C4880）, $\mathrm{C}$ マウントレンズ (F1.8), 暗箱, 制御用 PC から構成し た. 立米の化学発光イメージは, パイレックス製シャーレ に玄米 50 粒を配置し，リン酸緩衝溶液（pH 7.4） $0.9 \mathrm{ml}$ に $10 \mathrm{mmol} \mathrm{dm}{ }^{-3}$ ルミノール $1 \mathrm{ml}$ を加え, 更に終濃度が $0.5 \mathrm{~mol} \mathrm{dm}{ }^{-3}$ になるように $10 \mathrm{~mol} \mathrm{dm}{ }^{-3} \mathrm{H}_{2} \mathrm{O}_{2}$ を $0.1 \mathrm{ml}$ 加 えた後, 1 分後から撮影を開始し 1 分間積算して計測し た.また, 玄米由来の化学発光強度の定量值は, 微弱発光 計測装置（浜松ホトニクス製 C8801）を用い，パイレッ クス製シャーレに立米 30 粒を配置し, リン酸緩衝溶液

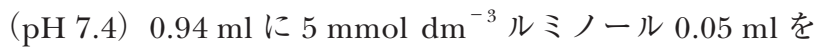
加え，更に終濃度が $1 \mathrm{mmol} \mathrm{dm}{ }^{-3}$ になるように $100 \mathrm{mmol}$ $\mathrm{dm}^{-3} \mathrm{H}_{2} \mathrm{O}_{2}$ を $0.01 \mathrm{ml}$ 加えた後，20 秒後から計測を開始 し, 蓄積時間 1 秒, 連続 5 回測定の平均值から求めた。

\section{3 結果と考察}

Fig. 1 に, 2001 年産コシヒカリ（冷蔵）のグアヤコー ル非存在下（A）と存在下（B）における化学発光イメー

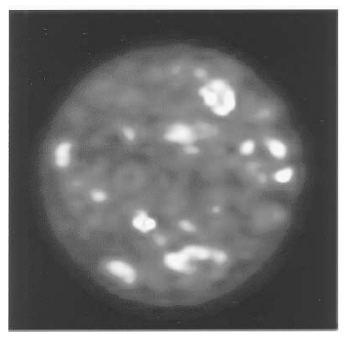

A

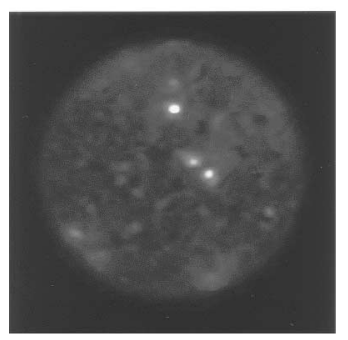

C

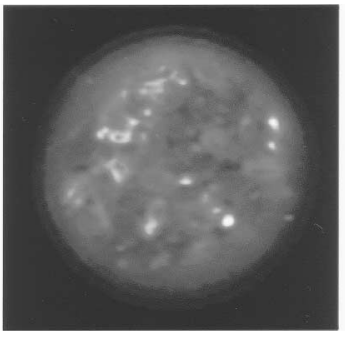

B

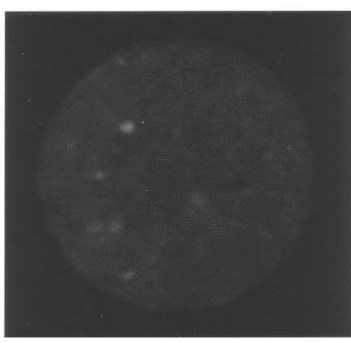

D
Fig. 2 Chemiluminescence images of some brown rice stored under various conditions

A: New brown rice with paddy; B: New brown rice; C: Old brown rice stored at $279 \mathrm{~K}$; D : Old brown rice stored at room temperature; The other conditions are the same as Fig. 1.

ジを示す。ペルオキシダーゼ基質の一つであるグアヤコー ルが共存すると発光強度が低下した. したがって，玄米の 発光がペルオキシダーゼ由来であることが証明された。

Fig. 2 に，2001 年産玄米 (古米) の冷蔵，2001 年産玄 米 (古米) の室温貯蔵, 2002 年産玄米（新米）籾付き及 び 2002 年産玄米 (新米) 籾無し（籾すり後 2 か月程度経 過）の化学発光画像を示す. 2002 年産玄米 (新米) 籾付 きが最も発光強度が高く, 2002 年産玄米 (新米) 籾無し, 2001 年産玄米（古米）の冷蔵 $\left(6^{\circ} \mathrm{C}\right) ， 2001$ 年産玄米（古 米）の室温貯蔵の順に発光強度が低下した。 また，発光画 像の解析から胚芽部分がやや強いものの米粒全体から発光 していることが分かった．これらの結果から，化学発光イ メージング法により玄米の古米, 新米の判別や貯蔵状態を 評価できることが分かった。

次に, 微弱発光計測装置を用い, 発光強度の定量化を行 った. Fig. 3 に, Fig. 2 と同じ玄米それぞれの定量值を示 す. 2002 年産玄米 (新米) 籾付きが最も発光強度が高く, 2002 年産玄米 (新米) 籾無し, 2001 年産玄米（古米）の 冷蔵 $\left(6^{\circ} \mathrm{C}\right), 2001$ 年産玄米（古米）の室温貯蔵の順に発 光強度が低下した。新米の籾付きと立米で約 5 倍, 古米 の冷蔵と室温貯蔵で約 2.5 倍, 2002 年産玄米 (新米) 籾 付きと 2001 年産玄米 (古米) の室温貯蔵で約 50 倍の強 度差であった。従来法の新米と古米の強度比は, ESR 法 


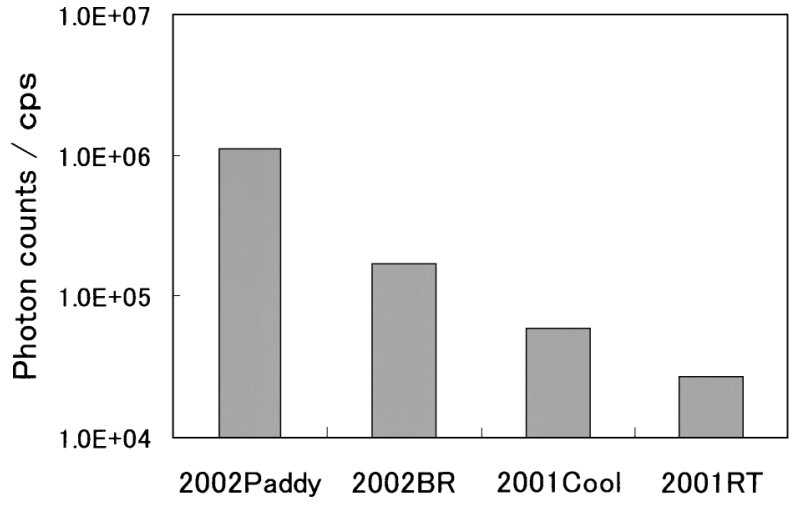

Fig. 3 Chemiluminescence intensity of brown rice stored under various conditions

Concentration of luminol: $0.5 \mathrm{mmol} \mathrm{dm}{ }^{-3}$; Concent-

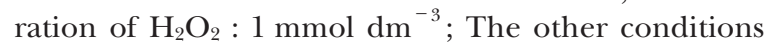
are the same as Fig. 2.

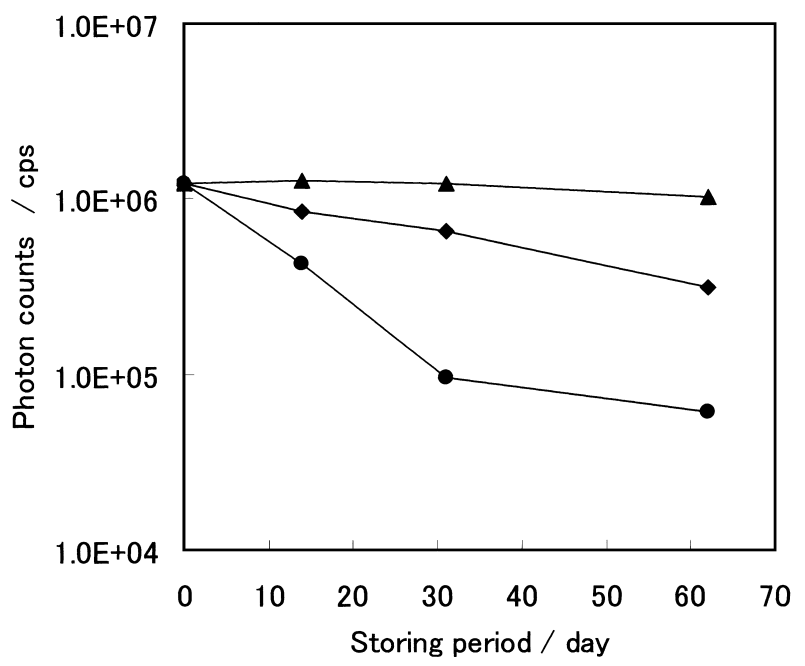

Fig. 4 Time course for the chemiluminescence intensity of brown rice stored under various conditions Closed triangle: Brown rice with paddy stored at 279K; Closed diamond: Brown rice stored at 279K; Closed circle: Brown rice stored at room temperature; The other conditions are the same as Fig. 3.

の場合で約 4 倍 ${ }^{1)}$, 蛍光画像法の場合で約 1.4 倍 ${ }^{4}$ であった. したがって, 化学発光法は, 従来法に比べ経時的鮮度変化 に対する発光強度のダイナミックレンジが広いことが分か った.

そこで，玄米の貯蔵状態の違いによる発光強度の経時変 化を検討した. Fig. 4 に, 貯蔵条件の違いによる発光強度 と貯蔵日数の関係を示す。低温籾貯蔵の場合，2 か月間で 発光強度はほとんど変化しなかった。一方，低温玄米貯蔵 の場合， 2 か月間で約 $1 / 3$ まで，室温貯蔵の場合，1 か月 間で約 1/10 まで低下した。Fig. 3 と Fig. 4 の結果から,

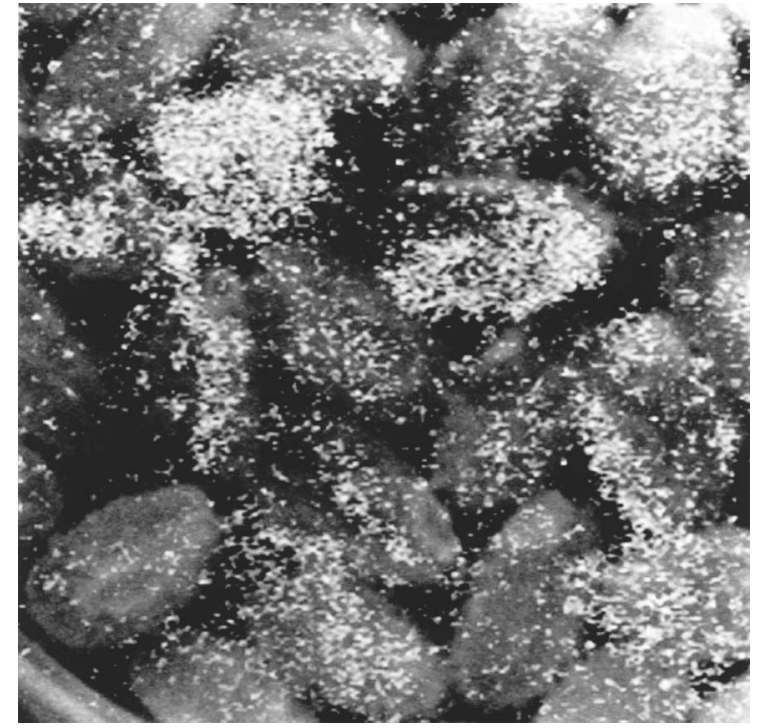

Fig. 5 Chemiluminescence image for a mixture of new rice and old rice (Chemiluminescence image was drawn over the photo image of brown rice)

The measuring conditions are the same as Fig. 1.

化学発光法により玄米の経時（短期）的な鮮度变化が高精 度に評価できることが分かった。

最後に, 玄米の経時的鮮度変化に対する化学発光強度の ダイナミックレンジが広いことを利用し，古米と新米の混 合した試料の判別を発光イメージの画像解析から試みた。 Fig. 5 に, 新米古米混合物の化学発光イメージを示す（玄 米写真イメージに白点の発光イメージを重ねて表示)．新 米と思われるものが明るく光り，古米で暗いという画像が 得られた。したがって，化学発光法により古米の混入も判 別できることが分かった.

\section{4 結 語}

ペルオキシダーゼを指標としたルミノール化学発光法に より, 玄米の経時的鮮度変化が従来法（ESR 法や蛍光画 像法）に比べ高精度に評価できることを見いだした。今 後, 更にデー夕を蓄積し, 生産者側（品質保証）や流通現 場（品質管理）で利用可能な米鮮度評価装置として実用化 する予定である。

$\left(\begin{array}{l}2003 \text { 年 } 9 \text { 月, 日本分析化学 } \\ \text { 会第 } 52 \text { 年会に扔いて発表 }\end{array}\right)$

\section{文献}

1) 野田博行: バイオサイエンスとインダストリー, $\mathbf{5 7}$, 175 (1999).

2) 山形県企業振興公社，株式会社山本製作所：日本特 許第 3162620 号.

3）山形県企業振興公社：日本特許公開広報，2001208745 . 
4) 野田博行, 後藤恒義, 大矢博昭, 鎌田 仁: 分析化 学 (Bunseki Kagaku), 51, 323 (2002).

5) 野田博行，後藤恒義：精米工業, 2004, 44.

6) 山形県企業振興公社：日本特許公開広報，2003-
172704.

7) 野田博行, 大矢博昭：日本分析化学会第 52 年会講 演要旨集, p. 327 (2003). 